Abstracta Iranica Abstracta Iranica

Revue bibliographique pour le domaine irano-aryen

Volume 24 | 2003

Comptes rendus des publications de 2001

\title{
Les éclosions de la beauté et les parfums de la majesté. Traduit de l'arabe et présenté par P. Ballanfat, Nîmes, Ed. de l'Eclat, 2001, 246 p.
}

\section{Pierre Lory}

\section{(2) OpenEdition}

Journals

Édition électronique

URL : http://journals.openedition.org/abstractairanica/34537

DOI : 10.4000/abstractairanica.34537

ISSN : 1961-960X

Éditeur :

CNRS (UMR 7528 Mondes iraniens et indiens), Éditions de l'IFRI

Édition imprimée

Date de publication : 15 mai 2003

ISSN : 0240-8910

Référence électronique

Pierre Lory, "Les éclosions de la beauté et les parfums de la majesté. Traduit de l'arabe et présenté par P. Ballanfat, Nîmes, Ed. de l'Eclat, 2001, 246 p. », Abstracta Iranica [En ligne], Volume 24 | 2003, document 174, mis en ligne le 05 janvier 2010, consulté le 25 septembre 2020. URL : http:// journals.openedition.org/abstractairanica/34537 ; DOI : https://doi.org/10.4000/abstractairanica. 34537

Ce document a été généré automatiquement le 25 septembre 2020.

Tous droits réservés 


\title{
Les éclosions de la beauté et les parfums de la majesté. Traduit de l'arabe et présenté par P. Ballanfat, Nîmes, Ed. de l'Eclat, 2001, 246 p.
}

\author{
Pierre Lory
}

Ce traité essentiel de mystique soufie avait été édité par Fritz Meier en 1957. Najm alDīn Kubrā y fait état avec une précision toute particulière du cheminement du soufi vers l'union au divin, notamment par des excursus sur la nature de l'expérience visionnaire, les couleurs, les sons, le symbolisme des lettres, l'évolution du désir amoureux. Il y apporte également des témoignages personnels sur son propre parcours, ce qui est plutôt rare dans ce genre de littérature. P. Ballanfat nous en livre ici une traduction soignée, rigoureuse, copieusement introduite (127 p. denses et éclairantes), annotée et complétée par des index, suivant en cela sa démarche pour plusieurs œuvres de Rūzbehān Baqlī.

\section{INDEX}

Thèmes : 8 . Soufisme 
AUTEURS

PIERRE LORY

EPHE - Paris 